ISSN 1678-3921

Journal homepage: www.embrapa.br/pab

For manuscript submission and journal contents, access: www.scielo.br/pab

\author{
Alexandre Perdigão(1) (iD, \\ Cyntia Ludovico Martins ${ }^{(2)}$ (D), \\ Luiz Carlos Vieira Junior(1), \\ Maria Márcia Pereira Sartori(3) (iD, \\ Maria Betânia Niehues ${ }^{(1 \otimes)}(\mathrm{ID})$ and \\ Mário De Beni Arrigoni(1) (iD \\ (1) Universidade Estadual Paulista Júlio de \\ Mesquita Filho, Faculdade de Medicina \\ Veterinária e Zootecnia, Departamento de \\ Melhoramento e Nutrição Animal, Campus \\ de Botucatu, Rua Prof. Dr. Walter Maurício \\ Corrêa, s/noํ, CEP 18618-681 Botucatu, SP \\ Brazil. \\ E-mail: perdigaoper@gmail.com, \\ vieirazoo@hotmail.com \\ beh_niehues@hotmail.com, \\ mario.arrigoni@unesp.br \\ (2) Universidade Estadual Paulista Júlio de \\ Mesquita Filho, Faculdade de Medicina \\ Veterinária e Zootecnia, Departamento \\ de Produção Animal e Medicina Animal \\ Preventiva, Campus de Botucatu, Rua \\ Prof. Dr. Walter Maurício Corrêa, s/no \\ 18618-681 Botucatu, SP, Brazil. \\ E-mail: cyntia.I.martins@unesp.br \\ (3) Universidade Estadual Paulista Júlio de \\ Mesquita Filho, Faculdade de Ciências \\ Agronômicas, Departamento de Produção \\ e Melhoramento Vegetal, Fazenda \\ Experimental Lageado, Rua José Barbosa \\ de Barros, № 1.780, Caixa Postal 237, CEP \\ 18610-307 Botucatu, SP, Brazil. \\ E-mail:mmpsartori@fca.unesp.br \\ $\bowtie$ Corresponding author
}

Received

May 19, 2019

Accepted

September 30, 2020

How to cite

PERDIGÃO, A.; MARTINS, C.L., VIEIRA JUNIOR, L.C.; SARTORI, M.M.P.; NIEHUES, M.B.; ARRIGONI, M.D.B. Identification of the production system of beef cattle by the stable isotope analysis. Pesquisa Agropecuária Brasileira, v.55, e01501, 2020. DOI: https://doi. org/10.1590/S1678-3921.pab2020.v55.01501.

\section{Identification of the production system of beef cattle by the stable isotope analysis}

\begin{abstract}
The objective of this work was to evaluate the potential of the stable isotope technique to characterize beef cattle production systems in tropical conditions. For this, carbon and nitrogen stable isotopes were identified in non-defatted and defatted bovine muscles. A total of 45 cattle were evaluated in three production systems: pasture, conventional feedlot, and young beef bull feedlot ( $\mathrm{n}=15$ per system). Samples from the Trapezius cervicis, Longissimus dorsi, and Semitendinosus muscles were collected to determine the isotopic composition of $\delta^{13} \mathrm{C}$ and $\delta^{15} \mathrm{~N}$. The isotopic data of the $\delta^{13} \mathrm{C}$ and $\delta^{15} \mathrm{~N}$ of non-defatted and defatted muscles were subjected to the principal component analysis (PCA) and to the discriminant analysis (DA). The PCA allowed separating the three production systems based on the results obtained for the non-defatted and defatted muscles. A correct global classification rate of $100 \%$ and a cross-validation rate of $100 \%$ were obtained with the DA. The carbon and nitrogen isotopic ratio of non-defatted and defatted muscles allows for the precise identification of beef cattle production systems in tropical conditions.
\end{abstract}

Index terms: muscle tissue, Nelore, production system, traceability.

\section{Identificação do sistema de produção de bovinos de corte pela análise de isótopos estáveis}

Resumo-O objetivo deste trabalho foi avaliar o potencial da técnica de isótopos estáveis para caracterizar sistemas de produção de carne bovina em condições tropicais. Para tanto, foram identificados isótopos estáveis de carbono e nitrogênio em músculos de bovinos não desengordurados e desengordurados. Avaliaram-se 45 bovinos criados em três sistemas de produção: a pasto, confinamento convencional e confinamento de novilhos superprecoces $(\mathrm{n}=15$ por sistema). Amostras dos músculos Trapezius cervicis, Longissimus dorsi e Semitendinosus foram coletadas para determinar a composição isotópica de $\delta^{13} \mathrm{C}$ e $\delta^{15} \mathrm{~N}$. Os dados isotópicos de $\delta^{13} \mathrm{C}$ e $\delta^{15} \mathrm{~N}$ em músculos não desengordurados e desengordurados foram submetidos à análise de componentes principais (ACP) e à análise discriminante (AD). A ACP permitiu a separação dos três sistemas de produção com base nos resultados obtidos para os músculos não desengordurados e desengordurados. Obtiveram-se uma taxa de classificação correta geral de $100 \%$ e uma taxa de validação cruzada de $100 \%$ com a AD. A razão isotópica de carbono e nitrogênio em músculos não desengordurados e desengordurados permite identificar com precisão os sistemas de produção de bovinos de corte em condições tropicais.

Termos para indexação: tecido muscular, Nelore, sistema de produção, rastreabilidade. 


\section{Introduction}

The Brazilian cattle industry produces around 10 million tons of beef, of which approximately $20.8 \%$ are exported to other countries, following rigorous quality standards (ABIEC, 2020). However, the production systems in Brazil are considered highly heterogeneous, which triggers several problems, especially related to health issues (Vinholis et al., 2016). In the country, Sistema Brasileiro de Identificação Individual de Bovinos e Búfalos (Sisbov) is the official system used for the traceability of bovine and bubaline from birth to slaughter, supporting decision making regarding the quality of national and imported cattle. However, this traceability is currently based on ear tags, life numbers, and electronic devices or tattoos, which can be lost or mislabeled (Guo et al., 2010). Therefore, a reliable and scientific system is urgently needed to characterize beef production in Brazil.

The possibility of determining how an animal was produced and where it was bred is an advance for the traceability and certification system in the country, meeting one of the requirements of the consumer markets to ensure the characteristics of the obtained product based on how it was handled before slaughter and also on its origin. A technique with potential to assess food authenticity is the stable isotope analysis, which allows to investigate food sources that are isotopically distinct (DeNiro \& Epstein, 1978).

The stable isotope and/or multielement analysis is an increasingly accepted tool for tracing the geographical origin of production animals, as well as for characterizing and differentiating their diet regime (González-Martin et al., 1999; Piasentier et al., 2003; Guo et al., 2010; Zhao et al., 2013). In Europe, stable isotopes are used to determine, according to production area and method, the quality of foods, in order to correctly label them, mainly those certified as having "protected designation of origin", "protected geographical indication", and "guaranteed traditional specialty" (Camin et al., 2017). In China, the technique is used to support the inspection and quality control of products in the markets (Chen et al., 2017).

The objective of this work was to evaluate the potential of the stable isotope technique to characterize beef cattle production systems in tropical conditions.

\section{Materials and Methods}

The guidelines followed for animal use were those established by the ethical committee for animal research (CEUA) of Universidade do Estado de São Paulo (UNESP), protocol number 169/2010-CEUA. A total of 45 cattle $(n=15$ per system) were evaluated in three production systems: pasture, conventional feedlot, and feedlot for young beef bulls.

In the pasture, located in the municipality of Novo Progresso, in the state of Pará, Brazil, the production animals were fed a diet strictly of palisade grass [Urochloa brizantha (A.Rich.) R.D.Webster 'Marandu'] forage. Slaughter occurred when the animals were approximately 36 months old.

In the conventional feedlot, the animals were kept 84 days. The finishing diet was composed of $15 \%$ sugarcane bagasse in natura, $43 \%$ corn grain silage, $18.5 \%$ citrus pulp, $20 \%$ cotton seed cake, $2.5 \%$ mineral supplement, and $1.0 \%$ urea. The animals were slaughtered at an approximate age of $24 \pm 6.86$ months.

In the young beef bull group, the experiment lasted 150 days at the experimental feedlot of UNESP, located in the municipality of Botucatu, in the state of São Paulo, Brazil. The animals were fed with a growing and finishing diet, containing 18 and $13 \%$ sugarcane bagasse in natura, $26.5 \%$ dry corn grain, $23 \%$ citrus pulp, $13 \%$ peanut bran, 15 and $20 \%$ rice bran, and $4.5 \%$ mineral supplement for young beef bull. The animals were slaughtered at 13 months.

To differentiate the feeding systems, 15 crossbred Nellore bulls were selected per system. Then, 150$\mathrm{g}$ samples were collected from the ingredients of each feed and also from the Trapezius cervicis, Longissimus dorsi, and Semitendinosus muscles, in order to determine the incorporation of $\delta^{13} \mathrm{C}$ and $\delta^{15} \mathrm{~N}$. The samples were stored under vacuum at $-20^{\circ} \mathrm{C}$ until isotopic measurement at the Center for Stable Isotopes of the Biosciences Institute of UNESP, also located in the municipality of Botucatu, in the state of São Paulo. In addition, samples from the ingredients of the production systems were analyzed and collected to assist in the interpretation of the results obtained for $\delta^{13} \mathrm{C}$ and $\delta^{15} \mathrm{~N}$ (Table 1).

For the isotopic analysis of carbon and nitrogen, the muscle samples were cut and dried in the MA035 forced-air oven (Marconi, Piracicaba, SP, Brazil), at $50^{\circ} \mathrm{C}$, for 48 hours. Afterwards, portions of the samples were defatted with ethyl ether in a Soxhlet

Pesq. agropec. bras., Brasília, v.55, e01501, 2020

DOI: 10.1590/S1678-3921.pab2020.v55.01501 
apparatus, at $65^{\circ} \mathrm{C}$, for 4 hours and then oven-dried, at $50^{\circ} \mathrm{C}$, for $30 \mathrm{~min}$ to allow the evaporation of the ether. All muscle samples were ground in the $2010 \mathrm{Geno} /$ Grinder cryogenic mill (Spex SamplePrep, Metuchen, NJ, USA), at $-196^{\circ} \mathrm{C}$. The samples were subsequently weighed, and 50-70 $\mu \mathrm{g}$ carbon and 500-600 $\mu \mathrm{g}$ nitrogen were put into $5 \times 3-\mathrm{mm}$ tin capsules and kept in the desiccator with $\mathrm{P}_{2} \mathrm{O}_{5}$ for 24 hours prior to the analysis.

After weighing, the capsules were placed in the Flash 2000 elemental analyzer (Thermo Fisher Scientific, Bremen, Germany) for isotope ratio mass spectrometry. The gases formed during the process $\left(\mathrm{CO}_{2}\right.$ and $\left.\mathrm{NO}_{\mathrm{x}}\right)$ were separated in a gas chromatographic column (3 $\mathrm{m} \times 6 \mathrm{~mm} \times 5 \mathrm{~mm}$ of inner diameter) and analyzed in the Delta V Advantage isotopic mass spectrometer (Thermo Fisher Scientific, Bremen, Germany) at the Center for Stable Isotopes of the Biosciences Institute of UNESP. The carbon and nitrogen isotope data were reported in $\delta$-notation in units of per thousands (\%) relative to the accepted international standards Vienna Pee Dee Belemnite (VPDB) and atmospheric air, respectively -, being calculated as follows:

$$
\delta(\text { sample; reference })=\left[\left(\mathrm{R}_{\text {sample }} / \mathrm{R}_{\text {reference }}\right)-1\right] \times 1000
$$

where $\delta$ is the relative enrichment of the sample in relation to the standard (dimensionless), and $\mathrm{R}$ is the isotopic ratio of the sample and standard (also dimensionless).

The reference working gases, $\mathrm{CO}_{2}$ and $\mathrm{N}_{2}$, were calibrated with the urea isotopic working standard IVA33802174 $\left(\delta^{13} \mathrm{C} \mathrm{PDB}=-39.73 \% ; \delta^{15} \mathrm{~N}\right.$ air $=0.73 \%$ ). The analytical precision was $0.2 \%$ for both carbon and nitrogen.

The isotopic data of the $\delta^{13} \mathrm{C}$ and $\delta^{15} \mathrm{~N}$ of the combination of non-defatted and defatted muscles were subjected to the multivariate analysis of variance, by the analysis of principal components (PCA), aiming to reduce the dimensionality of the data set and to describe all of the variability of the system using a smaller number of variables. The discriminant analysis was also performed to create a profile of the muscles, used to distinguish and classify them, better discriminating between the production systems. The statistical software used was Minitab, version 16.0 (Minitab, LLC, State College, PA, USA).

\section{Results and Discussion}

Based on the results of $\delta^{13} \mathrm{C}$ and $\delta^{15} \mathrm{~N}$ obtained for the bovine muscles (Table 2), the PCA allowed the discrimination of the three production systems (Figure 1). For the Trapezius cervicis muscle, the first principal component explained $82.6 \%$ of the variability among the systems, and the highest contribution was that of carbon in the non-defatted muscles. The first two components explained $99.3 \%$ of total variation. For the Longissimus dorsi muscle, the first major component explained $88.5 \%$ of the observed variability, with a higher contribution of nitrogen in the defatted muscles. The first two components explained 98.7\% of total variation. For the Semitendinosus muscle, the variability of the first principal component was $75.4 \%$, and the highest contribution was of carbon in the defatted muscles. The first two components explained $98.5 \%$ of total variation.

For the three muscles, both non-defatted and defatted, the values obtained by the PCA explained $81.7 \%$ of the observed variability, and the highest contribution was of nitrogen in the defatted Longissimus dorsi muscle. The first two components explained $97.5 \%$ of total variation (Figure 1).

The proportions of isotopes $\delta^{13} \mathrm{C}$ and $\delta^{15} \mathrm{~N}$ also allowed characterizing the three production systems evaluated. The samples from the young beef bull feedlot showed the highest $\delta^{13} \mathrm{C}$ values $(-18.23 \pm 0.59 \%$ for nondefatted muscles and $-17.75 \pm 0.40 \%$ o for defatted ones), compared with those of the conventional feedlot system

Table 1. Enrichment of $\delta^{13} \mathrm{C}$ and $\delta^{15} \mathrm{~N}$ in samples from diets $(\mathrm{n}=3)$ supplied in three different rearing systems during the production phases of beef cattle in Brazil.

\begin{tabular}{|c|c|c|c|c|c|c|}
\hline \multirow[t]{2}{*}{ Isotope } & \multicolumn{2}{|c|}{ Conventional feedlot } & \multicolumn{3}{|c|}{ Young beef bull feedlot } & \multirow{2}{*}{$\begin{array}{c}\text { Pasture } \\
\text { Breeding/Rearing/Finishing }\end{array}$} \\
\hline & Breeding/Rearing & Finishing & Breeding & Rearing & Finishing & \\
\hline$\delta^{13} \mathrm{C}(\%)$ & -14.24 & -18.85 & $-13.70 /-20.11$ & -22.18 & -23.07 & -14.41 \\
\hline$\delta^{15} \mathrm{~N}(\%)$ & 3.32 & 3.89 & $5.47 / 0.64$ & 4.35 & 4.52 & 13.80 \\
\hline
\end{tabular}


$(-15.16 \pm 0.65 \%$ for non-defatted and $-14.45 \pm 0.58 \%$ for defatted) and of the pasture $(-12.59 \pm 0.49 \%$ for nondefatted and $-12.24 \pm 0.46 \%$ for defatted). The highest $\delta^{15} \mathrm{~N}$ was found in the pasture system $(12.06 \pm 0.61 \%$ o for non-defatted and $12.15 \pm 0.58 \%$ for defatted), followed by the young beef bull feedlot $(7.24 \pm 0.37 \%$ o for non-defatted and $7.37 \pm 0.44 \%$ for defatted) and the conventional feedlot $(6.39 \pm 0.56 \%$ for non-defatted and $6.05 \pm 0.54 \%$ o for defatted).

In the discriminant analysis, the isotopic values of the non-defatted and defatted muscle samples were used to establish a classification model, which was then evaluated by a cross-validation procedure. An adequate classification was reached with a correct global classification rate of $100 \%$ and a crossvalidation rate of $100 \%$. This classification model can be used to clearly discriminate the samples between the production systems, regardless of the evaluated muscles.

Considering the obtained results and the different metabolic rates of the studied muscle tissues, it was possible to differentiate the dietary composition of the three production systems through the $\delta^{13} \mathrm{C}$ and $\delta^{15} \mathrm{~N}$ values of the non-defatted and defatted muscles. The proportions of the ingredients contained in each system influenced the isotopic values of carbon and nitrogen in the bovine muscles (Guo et al., 2010; Zhao et al., 2013). In the case of the pasture system, the animals were fed exclusively 'Marandu' palisade grass, characterized as a $\mathrm{C}_{4}$ forage, while, in the conventional feedlot and the young beef bull feedlot, the cattle were fed feeds with $\mathrm{C}_{3}$ and $\mathrm{C}_{4}$ plants (Table 2).
Lower $\delta^{13} \mathrm{C}$ values were found for the young beef bull feedlot. One possible explanation is that, before the intake of the diet, the cattle were creep fed during the rearing phase. Another is that the ingredients that make up this system are partly $\mathrm{C}_{3}$ plants, such as peanut meal, rice bran, citrus pulp, and soybean oil. De Smet et al. (2004), studying a feedlot of young beef bulls, found that the analysis of $\delta^{13} \mathrm{C}$ from tissues can be used as a method to track diets containing variable ratios of $\mathrm{C}_{3}$ and $\mathrm{C}_{4}$ plants.

The requirement of the young beef bulls for nondigestible protein in the rumen are higher (NRC, 1996) than that of the animals older than 18 months in the conventional feedlot system, increasing the use of $\mathrm{C}_{3}$ ingredients. In addition, the young bulls are kept longer in the feedlot system, favoring the exchange of the elements present in their diets, which are then incorporated into their tissues (Schwägele, 2005).

In a study testing the isotope technique in the traceability system for the authentication of animal products, Bahar et al. (2005) verified that the composition of the carbon and nitrogen stable isotopes in the bovine muscle changed considerably when grass silage $\left(C_{3}\right)$ was replaced by corn silage $\left(C_{4}\right)$ in the beef cattle diets. However, the muscle tissue evaluated was not suitable for short and recent changes in the diets, since, after 167 days of the experiment, tissue turnover had not been completed yet. This explains the results found in the present study, in which animals from the feedlot did not reach the isotope equilibrium level of the diet (Table 1).

Table 2. Values of $\delta^{13} \mathrm{C}$ and $\delta^{15} \mathrm{~N}$ in samples from non-defatted and defatted muscles of beef cattle in three rearing systems ${ }^{(1)}$.

\begin{tabular}{|c|c|c|c|c|c|c|}
\hline \multirow[t]{2}{*}{ Muscle } & \multicolumn{2}{|c|}{ Conventional feedlot } & \multicolumn{2}{|c|}{ Young beef bull feedlot } & \multicolumn{2}{|c|}{ Pasture } \\
\hline & Non-defatted & Defatted & Non-defatted & Defatted & Non-defatted & Defatted \\
\hline \multicolumn{7}{|c|}{ Trapezius cervicis } \\
\hline$\delta^{13} \mathrm{C}$ & $-15.22 \pm 0.47$ & $-14.45 \pm 0.59$ & $-19.02 \pm 0.56$ & $-17.86 \pm 0.25$ & $-12.4 \pm 0.36$ & $-12.01 \pm 0.32$ \\
\hline$\delta^{15} \mathrm{~N}$ & $6.56 \pm 0.39$ & $6.24 \pm 0.56$ & $7.72 \pm 0.30$ & $7.72 \pm 0.47$ & $11.99 \pm 0.61$ & $12.05 \pm 0.67$ \\
\hline \multicolumn{7}{|c|}{ Longissimus dorsi } \\
\hline$\delta^{13} \mathrm{C}$ & $-15.73 \pm 0.63$ & $-14.72 \pm 0.57$ & $-18.00 \pm 0.44$ & $-17.76 \pm 0.76$ & $-13.19 \pm 0.55$ & $-12.13 \pm 0.36$ \\
\hline$\delta^{15} \mathrm{~N}$ & $6.91 \pm 0.29$ & $6.32 \pm 0.35$ & $6.87 \pm 0.25$ & $7.13 \pm 0.37$ & $12.70 \pm 0.53$ & $12.68 \pm 0.60$ \\
\hline \multicolumn{7}{|c|}{ Semitendinosus } \\
\hline$\delta^{13} \mathrm{C}$ & $-14.54 \pm 0.85$ & $-13.75 \pm 0.45$ & $-17.67 \pm 0.35$ & $-17.62 \pm 0.25$ & $-12.18 \pm 0.34$ & $-12.57 \pm 0.93$ \\
\hline$\delta^{15} \mathrm{~N}$ & $5.72 \pm 0.59$ & $5.58 \pm 0.65$ & $7.13 \pm 0.27$ & $7.25 \pm 0.56$ & $11.48 \pm 0.53$ & $11.71 \pm 0.56$ \\
\hline
\end{tabular}

(1) Values are means \pm standard deviation. 
The $\delta^{15} \mathrm{~N}$ values in the muscles of the animals reared in the pasture were the highest. This is interesting since this area did not receive any type of soil fertilization, meaning that the nitrogen absorbed by the forage came only from the organic matter decomposed on the soil. Some studies have shown that the nitrogen in animal muscles is characterized predominantly by the consumed diet and the local soil (Inácio \& Chalk, 2017; Piasentier et al., 2003). Moreover, $\delta^{15} \mathrm{~N}$ can reach values around $10 \%$ in soils with a high organic matter content (Shibuya et al., 2006), confirming the results obtained in this system in the present study.

In the conventional and young beef bull feedlots, the diets were composed mainly of grains, whose productivity is often increased through inorganic
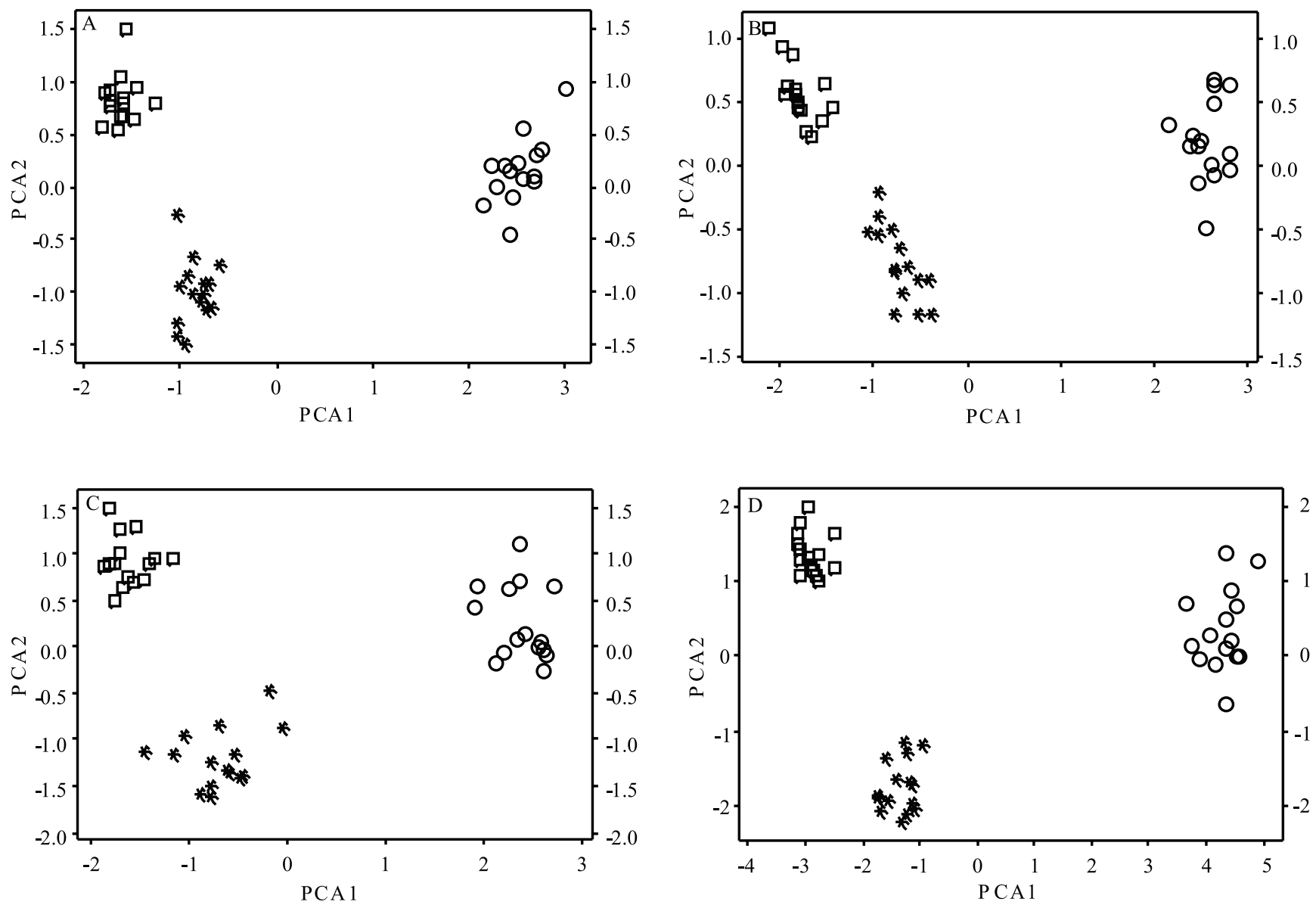

* Conventional feedlot $\square$ Young beef bull feedlot $\quad$ Pasture

Figure 1. Principal component analysis of the following non-defatted and defatted muscles: Trapezius cervicis (A), Longissimus dorsi (B), and Semitendinosus (C), as well as the mean values of all muscles (D) in three production systems. 
there was a prevalence of $62.6 \%$ oxidative fibers, while, in the Longissimus dorsi and Semitendinosus muscles, the glycolytic fibers represented the largest portions of 43.2 and $49.7 \%$, respectively (Kirchofer et al., 2002). Oxidative fibers are closely linked to a high metabolism and oxygen-exchange dependency, being richly vascularized and having a large number of mitochondria (Macari et al., 1994), whereas glycolytic fibers show a reduced density of blood capillaries, with consequently small changes in the metabolites (Banks, 1992). Therefore, the greater the exchange of metabolites, the faster the muscles reflect the signal of the diet change, which can be observed in the total values of the coefficients of variability of the PCA for the Trapezius cervicis muscle. In addition, the type of production system adopted influences the physicochemical and qualitative characteristics of the muscles due to the level of physical activity, amount of concentrate in the diet, and, to a lesser extent, animal age (Therkildsen et al., 1998; Vestergaard et al., 2000).

When defatted, both the Longissimus dorsi and Trapezius cervicis muscles showed a greater enrichment in the assessed elements, i.e., $\delta^{13} \mathrm{C}=$ $0.77 \%$ and $\delta^{15} \mathrm{~N}=0.11 \%$ and $\delta^{13} \mathrm{C}=0.63 \%$ and $\delta^{15} \mathrm{~N}$ $=0.09 \%$, respectively; the Semitendinosus muscle was less affected, with $\delta^{13} \mathrm{C}=0.15 \%$ and $\delta^{15} \mathrm{~N}=-0.07 \%$. This may be attributed to the increased presence of intramuscular fat in these muscles, which has a positive correlation with the type of fiber in the tissue (Hwang et al., 2010), since the Longissimus dorsi muscle has $10.7 \%$ more oxidative fibers than the Semitendinosus muscle. Moreover, the deposition of intramuscular fat occurs later in the carcass and is directly linked to the amount of energy in the diet (Silva et al., 2009), showing a better isotopic signature of the biological elements in the tissue.

\section{Conclusion}

The carbon and nitrogen isotopic ratio of the Trapezius cervicis, Longissimus dorsi, and Semitendinosus non-defatted and defatted muscles allows for the precise identification of beef cattle production systems in tropical conditions.

\section{Acknowledgments}

To Fundação de Amparo à Pesquisa do Estado de São Paulo (Fapesp), for financial support and to
Centro Isótopos Estáveis Prof. Dr. Carlos Ducati of Instituto de Biocências of Universidade Estadual Paulista (Unesp) Botucatu, for all the technical and infrastructure support.

\section{References}

ABIEC. Associação Brasileira das Indústrias Exportadoras de Carnes. Beef Report: perfil da pecuária no Brasil 2020. Available at: <http://abiec.com.br/publicacoes/beef-report-2020/>. Accessed on: Aug. 212020.

BAHAR, B.; MONAHAN, F.J.; MOLONEY, A.P.; O'KIELY, P.; SCRIMGEOUR, C.M.; SCHMIDT, O. Alteration of the carbon and nitrogen stable isotope composition of beef by substitution of grass silage with maize silage. Rapid Communications in Mass Spectrometry, v.19, p.1937-1942, 2005. DOI: https://doi.org/10.1002/rcm.2007.

BANKS, W.J. Histologia veterinária aplicada. São Paulo: Manole, 1992.

CAMIN, F.; BONER, M.; BONTEMPO, L.; FAUHL-HASSEK, C.; KELLY, S.D.; RIEDL, J.; ROSSMANN, A. Stable isotope techniques for verifying the declared geographical origin of food in legal cases. Trends in Food Science \& Technology, v.61, p.176-187, 2017. DOI: https://doi.org/10.1016/j.tifs.2016.12.007.

CHEN, T.; CHEN, G.; YANG, S.; ZHAO, Y.; HA, Y.; YE, Z. Recent developments in the application of nuclear technology in agro-food quality and safety control in China. Food Control, v.72, p.306-312, 2017. DOI: https://doi.org/10.1016/j. foodcont.2015.08.034.

DE SMET, S.; BALCAEN, A.; ClAEYS, E.; BOECKX, P.; CLEEMPUT, O. van. Stable carbon isotope analysis of different tissues of beef animals in relation to their diet. Rapid Communications in Mass Spectrometry, v.18, p.1227-1232, 2004. DOI: https://doi.org/10.1002/rcm.1471.

DENIRO, M.J.; EPSTEIN, S. Influence of diet on the distribution of carbon isotopes in animals. Geochimica et Cosmochimica Acta, v.42, p.495-506, 1978. DOI: https://doi.org/10.1016/00167037(78)90199-0.

GANNES, L.Z.; O'BRIEN, D.M.; RIO, C.M. del. Stable isotopes in animal ecology: assumptions, caveats, and a call for more laboratory experiments. Ecology, v.78, p.1271-1276, 1997. DOI: https://doi.org/10.1890/0012-9658(1997)078[1271:SIIAEA]2.0. $\mathrm{CO} ; 2$.

GONZÁLEZ-MARTIN, I.; GONZÁLES-PÉREZ, C.; HERNÁNDEZ MÉNDEZ, J.; MARQUÉS-MACIAS, E.; POVEDA, F.S. Use of isotope analysis to characterize meat from Iberian-breed swine. Meat Science, v.52, p.437-441, 1999. DOI: https://doi.org/10.1016/s0309-1740(99)00027-3.

GUO, B.L.; WEI, Y.M.; PAN, J.R; LI, Y. Stable C and N isotope ratio analysis for regional geographical traceability of cattle in China. Food Chemistry, v.118, p.915-920, 2010. DOI: https://doi.org/10.1016/j.foodchem.2008.09.062. 
HANDLEY, L.L.; RAVEN, J.A. The use of natural abundance of nitrogen isotopes in plant physiology and ecology. Plant, Cell \& Environment, v.15, p.965-985, 1992. DOI: https://doi.org/10.1111/j.1365-3040.1992.tb01650.x.

HWANG, Y.-H.; KIM, G.-D.; JEONG, J.-Y.; HUR, S.-J.; JOO, S.-T. The relationship between muscle fiber characteristics and meat quality traits of highly marbled Hanwoo (Korean native cattle) steers. Meat Science, v.86, p.456-461, 2010. DOI: https://doi.org/10.1016/j.meatsci.2010.05.034.

INÁCIO, C.T.; CHALK, P.M. Principles and limitations of stable isotopes in differentiating organic and conventional foodstuffs: 2. Animal products. Critical Reviews in Food Science and Nutrition, v.57, p.181-196, 2017. DOI: https://doi.org/10.1080/10 408398.2014.887056.

KIRCHOFER, K.S.; CALKINS, C.R.; GWARTNEY, B.L. Fiber-type composition of muscles of the beef chuck and round. Journal of Animal Science, v.80, p.2872-2878, 2002. DOI: https://doi.org/10.2527/2002.80112872x.

MACARI, M.; FURLAN, R.L.; GONZALES, E. Fisiologia aviária aplicada a frangos de corte. Jaboticabal: Funep/Unesp, 1994. 246p.

NRC. National Research Council. Nutrient requirements of beef cattle. $7^{\text {th }}$ rev. ed. Washington: National Academy Press, 1996.

PIASENTIER, E.; VALUSSO, R.; CAMIN, F.; VERSINI, G. Stable isotope ratio analysis for authentication of lamb meat. Meat Science, v.64, p.239-247, 2003. DOI: https://doi.org/10.1016/ s0309-1740(02)00183-3.

SCHWÄGELE, F. Traceability from a European perspective. Meat Science, v.71, p.164-173, 2005. DOI: https://doi.org/10.1016/j. meatsci.2005.03.002.

SHIBUYA, E.K.; SARKIS, J.E.S.; NEGRINI NETO, O.; MOREIRA, M.Z.; VICTORIA, R.L. Sourcing Brazilian marijuana by applying IRMS analysis to seized samples. Forensic Science International, v.160, p.35-43, 2006. DOI: https://doi.org/10.1016/j.forsciint.2005.08.011.
SILVA, S. da L. e; LEME, P.R.; PUTRINO, S.M.; PEREIRA, A.S.C.; VALINOTE, A.C.; NOGUEIRA FILHO, J.C.M.; LANNA, D.P.D. Fatty acid composition of intramuscular fat from Nellore steers fed dry or high moisture corn and calcium salts of fatty acids. Livestock Science, v.122, p.290-295, 2009. DOI: https://doi.org/10.1016/j.livsci.2008.09.013.

THERKILDSEN, M.; VESTERGAARD, M.; JENSEN, L.R.; ANDERSEN, H.R.; SEJRSEN, K. Effect of feeding level, grazing and finishing on growth and carcass quality of young Friesian bulls. Acta Agriculturae Scandinavica, Section A - Animal Science, v.48, p.193-201, 1998. DOI: https://doi.org/10.1080/09064709809362420.

VESTERGAARD, M.; OKSBJERG, N.; HENCKEL, P. Influence of feeding intensity, grazing and finishing feeding on muscle fibre characteristics and meat colour of semitendinosus, longissimus dorsi and supraspinatus muscles of young bulls. Meat Science, v.54, p.177-185, 2000. DOI: https://doi.org/10.1016/s03091740(99)00097-2.

VINHOLIS, M. de M.B.; SOUZA FILHO, H.M. de; CARRER, M.J.; BARIONI JUNIOR, W.; CHADDAD, F.R. Complementarity in the adoption of traceability of beef cattle in Brazil. Production, v.26, p.540-550, 2016. DOI: https://doi.org/10.1590/01036513.193615 .

WERNER, R.A.; SCHMIDT, H.-L. The in vivo nitrogen isotope discrimination among organic plant compounds. Phytochemistry, v.61, p.465-484, 2002. DOI: https://doi.org/10.1016/s00319422(02)00204-2.

YONEYAMA, T. Characterization of natural ${ }^{15} \mathrm{~N}$ abundance of soils. In: BOUTTON, T.W., YAMASAKI, S.-I. (Ed.). Mass spectrometry of soils. New York: Marcel-Dekker, Inc., 1996. p.205-223.

ZHAO, Y.; ZHANG, B.; CHEN, G.; CHEN, A.; YANG, S.; YE, $Z$. Tracing the geographic origin of beef in China on the basis of the combination of stable isotopes and multielement analysis. Journal of Agricultural and Food Chemistry, v.61, p.70557060, 2013. DOI: https://doi.org/10.1021/jf400947y. 